\title{
THE ASSOCIATION OF ZINC WITH SOME COMPONENTS OF BOAR VESICULAR SECRETION AND SEMINAL PLASMA
}

\author{
I. GEL-FILTRATION AND DIALYSIS STUDIES \\ J. C. BOURSNELL, P. A. BRIGGS, U. LAVON* AND E. J. BUTLER $\dagger$ \\ A.R.C. Unit of Reproductive Physiology and Biochemistry, Cambridge $\ddagger$ and \\ $\dagger$ Houghton Poultry Research Station, Houghton, Hunts.
}

(Received 27th June 1972)

\begin{abstract}
Summary. Gel-filtration and dialysis studies on the state of zinc in boar seminal plasma and vesicular secretion strongly suggest that the zinc is partitioned between two or more ligands of which the most likely are proteins and citrate. This partition is very sensitive to changes in $\mathrm{pH}$ and buffer composition and an increasing proportion of the zinc is precipitated at $\mathrm{pH}$ values above 7 . No firmly bound protein-zinc complex was found which could account for the close correlation between the zinc and protein nitrogen contents previously observed for these fluids.
\end{abstract}

\section{INTRODUCTION}

In a previous paper (Boursnell, Baronos, Briggs \& Butler, 1972), it was shown that the concentration of zinc in boar vesicular secretion and seminal plasma was positively correlated with those of zinc-binding substances, such as total and non-dialysable nitrogenous components and citrate. The correlation with these nitrogenous substances was particularly strong $(P<0 \cdot 001)$ in the seminal plasma of individual animals and there was evidence that these associations were independent of the zinc-citrate relationship. The correlation between zinc and the nitrogenous substances suggested the possibility of a strong association between the zinc and one or more of the proteins present in these fluids.

The work reported in this paper is part of an investigation of the combination of zinc with some of the ligands in these fluids, particularly the proteins and citrate.

\section{MATERIALS AND METHODS}

Seminal plasma, vesicular secretion and epididymal plasma

Seminal plasma was obtained from whole semen collected by artificial vagina from boars housed at the Animal Research Station. Immediately after

* Present address: Department of Zoology, University of Tel Aviv, Israel.

$\ddagger$ Postal address: Animal Research Station, 307 Huntingdon Road, Cambridge CB3 0JQ. 
collection, the gel was removed by straining through muslin and the spermatozoa were separated by centrifugation $(10,000 \mathrm{~g}$ for $20 \mathrm{~min})$. Vesicular secretion was obtained by natural drainage from freshly excised seminal vesicles obtained from slaughterhouse material. Epididymal plasma was prepared as described by Lavon \& Boursnell (1971). The fluids were stored at $-25^{\circ} \mathrm{C}$ until required.

\section{Gel filtration}

This was carried out as described by Boursnell \& Briggs (1969) using Sephadex G-200 (Pharmacia (Great Britain) Ltd, London) and a Chromafrac and Chromapump (Baird \& Tatlock Ltd, Chadwell Heath, Essex). Protein in the fractions was monitored at 280 or $256 \mathrm{~nm}$ with a Uvicord II detector and recorder (L.K.B. Instruments Ltd, South Croydon, Surrey).

\section{Buffers and reagents}

These were usually prepared as described by Miller \& Golder (1950) from Analar materials where these were available. Universal buffer (Prideaux \& Ward, 1924) and a 0.02 $\mathrm{M}$-sodium carbonate-bicarbonate buffer at $\mathrm{pH} 9$ were also used.

\section{Removal of traces of contaminating zinc}

The apparatus was pre-cleaned by soaking in $6 \mathrm{~N}-\mathrm{HCl}$ and rinsing with deionized water. In subsequent use, the apparatus, after normal cleaning in detergent, was rinsed in slightly acidified $(\mathrm{HCl})$ tap water before a final rinse with acidified deionized water.

\section{Zinc, citrate, ergothioneine and amino acid determinations}

Zinc was determined with an atomic absorption spectrophotometer SP 90 (Pye Unicam Ltd, Cambridge, U.K.) using an air-acetylene or air-propane flame. The sample was diluted if necessary with a $\mathrm{pH} 4$ citrate buffer. Citrate was determined on suitable aliquots by the method of Speck, Moulder \& Evans (1946) as modified by Mann, Davies \& Humphrey (1949). Ergothioneine was determined by the modification of Mann (1964) of the method of Hunter (1949). Amino acids were detected by the ninhydrin method of Plancot \& Han (1969).

\section{Preparation of zinc citrate solutions}

These were prepared by dissolving the calculated amount of zinc acetate in $0.0067 \mathrm{M}$-citrate buffer to give concentrations of zinc and citrate simulating those in seminal plasma. Values of $\mathrm{pH}$ beyond the citrate buffer range were obtained by the addition of veronal buffer (Miller \& Golder, 1950).

\section{Preparation of $A$ Dial and $B$ Dial}

These were separated by prolonged dialysis at $\mathrm{pH} 8, I=0.015$, and the $\mathrm{B}$ Dial centrifuged from the supernatant solution of A Dial (Boursnell \& Nelson, 1965). The complex B Dial comprises proteins $\mathbf{B}$ and $\mathbf{H}$ which are separable (Boursnell \& Briggs, 1969), but other minor components are present in this material as well as in the A Dial (Lavon, Boursnell \& Briggs, 1972). 


\section{RESULTS}

In the early part of this work, difficulties in obtaining reliable duplicate estimations were attributed to partial precipitation of zinc from seminal plasma and vesicular secretion caused by the relatively alkaline $\mathrm{pH}$ of the media. This effect was confirmed by measurements on six seminal plasma and two vesicular secretion samples, each diluted $25 \times$ or $100 \times$, respectively, with both $\mathrm{pH} 9$, $I=0 \cdot 3$, buffer and with $0.01 \mathrm{M}$-citric acid. Four or five replicate determinations showed that the use of the acid diluent increased the observed zinc concentration in these fluids although the increases obtained (10 to $30 \%$ with seminal plasma) differed from one sample to another; the increases with the two vesicular secretion samples were less $(4 \%$ and $5 \%$ ) than with the seminal plasma samples.

Similar determinations on eighteen aliquots of zinc citrate $(\mathrm{pH} 9)$ showed that acidification as above increased the amount of zinc determined by $9 \%$ and also that the replicates agreed more closely than the determinations on the biological fluids.

Because of these difficulties, in subsequent work, all samples for zinc determination were acidified to prevent precipitation of zinc and great care was taken to obtain reliable replicate values of zinc in these biological fluids.

\section{GEL FILTRATION EXPERIMENTS}

\section{Distribution of zinc in gel filtration fractions}

Three samples of vesicular secretion and four of seminal plasma of widely differing zinc contents (vesicular secretion, 121 to $163 \mu \mathrm{g} \mathrm{Zn} / \mathrm{ml}$; seminal plasma, 4 to $43 \mu \mathrm{g} \mathrm{Zn} / \mathrm{ml}$ ) were fractionated by gel filtration both at $\mathrm{pH} 4$ and 5 (acetate buffer, $I=0 \cdot 3$ ). No zinc was found under the protein peaks but a pronounced peak, accounting for all the zinc in the samples applied, occurred in the region of the low molecular weight substances which are not individually separable by the G-200 Sephadex. The organic components and the u.v. absorption spectrum of this peak, which is more prominent at $256 \mathrm{~nm}$ than at $280 \mathrm{~nm}$, were further investigated. A typical gel-filtration pattern is shown in Text-fig. 1 .

In an extension of this work, three seminal plasma and three vesicular secretion samples were fractionated using $\mathrm{pH} 7$ (phosphate) and $\mathrm{pH} 8$ and 9 (veronal) buffers. The means of the rather variable recoveries of zinc from the column fractions were: vesicular secretion, $91 \%$; and seminal plasma, $81 \%$. A small percentage of zinc in the samples applied was located under the excluded Protein $\mathrm{B}$ peak; the mean values observed were slightly lower with vesicular secretion $(\mathrm{pH} 7,1.7 \% ; \mathrm{pH} 8,2.4 \% ; \mathrm{pH} \mathrm{9,3.1 \% )} \mathrm{than} \mathrm{with} \mathrm{seminal} \mathrm{plasma}$ $(\mathrm{pH} 7,1.7 \% ; \mathrm{pH} 8,2.9 \% ; \mathrm{pH} \mathrm{9,6.6 \% ).} \mathrm{Further} \mathrm{comparable} \mathrm{tests} \mathrm{at} \mathrm{pH} 6$ (phosphate buffer) showed complete recovery of the zinc in the low molecular weight peak.

As mentioned by Lavon, Briggs \& Boursnell (1973), a haze always occurred in gel-filtration fractions containing the excluded protein $\mathrm{B}$ at all $\mathrm{pH}$ values from 4 to 9 with both seminal plasma and vesicular secretion. This haze could be eliminated by prior centrifuging $(35,000 \mathrm{~g}$ for $20 \mathrm{~min})$ of either material. The 
resulting centrifuged precipitate had a $\mathrm{Zn} / \mathrm{N}$ ratio less than that of the supernatant fluid and a $\mathrm{P} / \mathrm{N}$ ratio of 0.04 . Thus the haze, which is not soluble in 0.01 M-citric acid, had apparently no significant connection with the main zinc distribution on the column and may merely represent cell débris and bacteria. Spermatozoa were not detected.

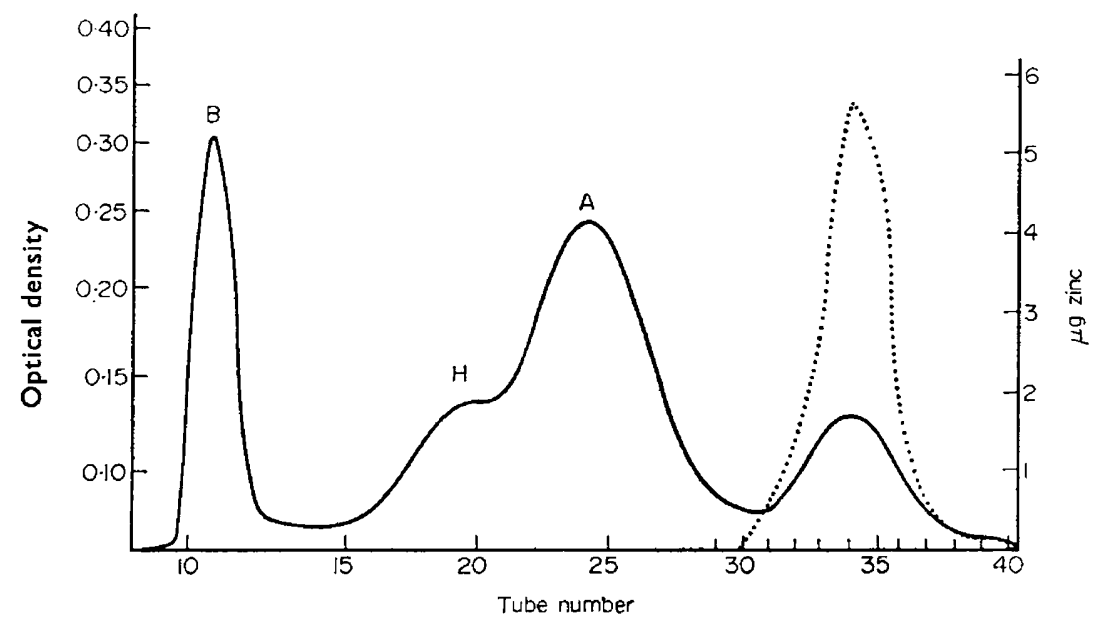

Text-Fig. 1. Distribution of zinc in protein (A, B and $\mathrm{H}$ ) and low molecular weight fractions collected from G-200 Sephadex gel-filtration column. Pooled seminal plasma collections from Boar O. Buffer, $\mathrm{pH} 4, I=0.3$ (Miller \& Golder, 1950). Protein and low molecular weight u.v.-absorbing material $(280 \mathrm{~nm})$, —; zinc, $\cdots \cdots$.

The loss of zinc (9\% with vesicular secretion; $19 \%$ with seminal plasma) occurring during the fractionations at alkaline $\mathrm{pH}$ values could not be accounted for by the negligible amount of zinc recovered by routine washing at $\mathrm{pH} 4$, $I=0 \cdot 3$, of the columns at the end of each set of fractionations at $\mathrm{pH} 7,8$ or 9 , nor by the minor variations in the low zinc content of the buffers used. Even greater losses of zinc were encountered in other experiments. In one case, four consecutive aliquots of a seminal plasma sample were run at $\mathrm{pH} 9$ (phosphate buffer). The mean recovery of zinc was only $59.5 \%$ (S.E.M., $2 \cdot 3$ ). Immediately following this experiment, four aliquots of zinc citrate containing $30 \mu \mathrm{g} \mathrm{Zn} / \mathrm{ml}$ were similarly run. The mean percentage of zinc recovered was close $(56.2 \%$; S.E.M., 1.0 ) to that obtained with the seminal plasma. Again, the zinc was not recovered by washing the column at $\mathrm{pH} 4$ or even with a final wash at $\mathrm{pH} 3$.

It was discovered, as described, that the major reason for these losses was the failure of the atomic absorption method to respond fully to zinc present in alkaline media, presumably due to precipitation of the zinc. Acidification of the column fractions to about $\mathrm{pH} 5$ with $\mathrm{HCl}$ enhanced the response and the recovery of zinc from such columns was subsequently found to be substantially complete.

Distribution of zinc in the low molecular weight gel filtration fractions

It was noticed that, apart from the decreased 'recovery' of zinc at the higher $\mathrm{pH}$ values (8 and 9 in particular), there was a decrease in the sharpness of the 
peak and a progressive broadening of it from $\mathrm{pH} 7$ to 9 . The distribution of the zinc (Tables 1 and 2) was reasonably close to that of the normal (Gaussian) curve, as established by calculation of the kurtosis and skewness coefficients (Kendall \& Stuart, 1963). The variance $\left(\sigma^{2}\right)$ of the curves was also determined.

Table 1. Analysis of curves of zinc distribution in low molecular weight gel-filtration fractions of boar vesicular secretion

\begin{tabular}{|c|c|c|c|c|c|c|c|}
\hline & 4 & 5 & 6 & 7 & 8 & 9 & $\begin{array}{l}\text { Date of } \\
\text { sample }\end{array}$ \\
\hline $\begin{array}{l}\text { No of vesicular } \\
\text { secretion samples }\end{array}$ & 2 & 3 & 2 & 3 & 3 & 3 & \\
\hline Mean kurtosis & $3 \cdot 2$ & $3 \cdot 2$ & $3 \cdot 4$ & $6 \cdot 1$ & $6 \cdot 5$ & $4 \cdot 0$ & \\
\hline Mean variance & 1.05 & $3 \cdot 07$ & $4 \cdot 20$ & $2 \cdot 02$ & $5 \cdot 85$ & $12 \cdot 02$ & \\
\hline $\begin{array}{l}\text { Total no. of } \\
\text { fraction tubes } \\
\text { containing } \\
\text { significant } \mathrm{Zn}\end{array}$ & $\begin{array}{l}8 \\
7 \\
-\end{array}$ & $\begin{array}{l}13 \\
\frac{12}{10}\end{array}$ & $\begin{array}{r}16 \\
14 \\
-\end{array}$ & $\begin{array}{l}11 \\
11 \\
13\end{array}$ & $\begin{array}{l}24 \\
18 \\
16\end{array}$ & $\begin{array}{l}19 \\
18 \\
20\end{array}$ & $\begin{array}{r}17-6-70 \\
27-1-71 \\
23-2-71 \\
3-2-70\end{array}$ \\
\hline $\begin{array}{l}\text { No. of fraction } \\
\text { tubes containing } \\
\text { Zn on the 'protein' } \\
\text { side of the peak }\end{array}$ & $\begin{array}{l}4 \\
3 \\
-\end{array}$ & $\begin{array}{l}6 \\
6 \\
5\end{array}$ & $\begin{array}{l}8 \\
7 \\
-\end{array}$ & $\begin{array}{l}4 \\
3 \\
6\end{array}$ & $\begin{array}{r}11 \\
11 \\
9\end{array}$ & $\begin{array}{r}11 \\
9 \\
11\end{array}$ & $\begin{array}{r}17-6-70 \\
27-1-71 \\
23-2-71 \\
3-2-70\end{array}$ \\
\hline
\end{tabular}

Table 2. Analysis of curves of zinc distribution in low molecular weight gelfiltration fractions of boar seminal plasma

\begin{tabular}{|c|c|c|c|c|c|c|c|}
\hline & 4 & 5 & 6 & 7 & 8 & 9 & Boar \\
\hline $\begin{array}{l}\text { No. of seminal } \\
\text { plasma samples }\end{array}$ & 2 & 2 & 2 & 3 & 3 & 3 & \\
\hline Mean kurtosis & $4 \cdot 2$ & $3 \cdot 4$ & 3.9 & $5 \cdot 2$ & $4 \cdot 3$ & $3 \cdot 3$ & \\
\hline Mean variance & $1 \cdot 8$ & $3 \cdot 2$ & $4 \cdot 1$ & $4 \cdot 2$ & $7 \cdot 6$ & $12 \cdot 4$ & \\
\hline $\begin{array}{l}\text { Total no. of } \\
\text { fraction tubes } \\
\text { containing } \\
\text { significant } \mathrm{Zn}\end{array}$ & $\begin{array}{r}8 \\
11 \\
-\end{array}$ & $\begin{array}{l}14 \\
12 \\
-\end{array}$ & $\begin{array}{l}15 \\
17 \\
-\end{array}$ & $\begin{array}{l}15 \\
18 \\
11\end{array}$ & $\begin{array}{l}19 \\
20 \\
16\end{array}$ & $\begin{array}{l}20 \\
20 \\
16\end{array}$ & $\begin{array}{l}\mathrm{A} \\
\mathrm{O} \\
\mathrm{E}\end{array}$ \\
\hline $\begin{array}{l}\text { No. of fraction } \\
\text { tubes containing } \\
\mathrm{Zn} \text { on the 'protein' } \\
\text { side of the peak }\end{array}$ & $\begin{array}{l}3 \\
4 \\
\end{array}$ & $\begin{array}{l}6 \\
7 \\
-\end{array}$ & $\begin{array}{l}8 \\
8 \\
-\end{array}$ & $\begin{array}{l}5 \\
7 \\
4\end{array}$ & $\begin{array}{r}9 \\
10 \\
6\end{array}$ & $\begin{array}{r}10 \\
10 \\
7\end{array}$ & $\begin{array}{l}\mathrm{A} \\
\mathrm{O} \\
\mathrm{E}\end{array}$ \\
\hline
\end{tabular}

In these Tables, the number of column fractions containing significant quantities of zinc associated with the peak are represented in two ways: (1) the total number of such fractions on both sides of and including the peak value, and (2) those tubes on the 'protein' side of the peak but excluding the peak maximum value. The two reasons for this double presentation are (a) to establish the approximate symmetry of the peak and (b) to obviate the occasional possible extension of the minor values of zinc beyond the cut-off of the column.

The area of the peaks, calculated from the height and standard deviation $(\sigma)$ corresponded with the total zinc contents of the peaks.

The decrease in the height of the peaks from $\mathrm{pH} 7$ to 9 was also partly caused by 'tailing'. This was demonstrated by a relatively symmetrical increase in the 
number of tubes containing quantities of zinc significantly greater than the background. This increase was not shown by gel-filtration runs of zinc citrate at $\mathrm{pH} \mathrm{7,8}$ and 9 in the absence of protein. Comparable studies of the breadth of the zinc and citrate peaks at $\mathrm{pH} 9$ given by four samples of seminal plasma from three animals also showed that the citrate peak revealed no evidence of the 'tailing' which was pronounced in the zinc peaks in all four cases.

The skewness coefficients, all between 1.0 and $-0 \cdot 9$, are small and randomly distributed. The influence of the 'tails' of the peaks upon this coefficient is extremely great and it can be stated that the zinc distributions are without significant skewness.

Table 3. Percentages of boar seminal plasma zinc in gel-filtration column fractions under Protein B and in the region between this and the low molecular weight peak

\begin{tabular}{|c|c|c|c|}
\hline \multirow{2}{*}{$\begin{array}{l}\text { pH of } \\
\text { running } \\
\text { buffer }\end{array}$} & \multirow[b]{2}{*}{ Buffer composition } & \multicolumn{2}{|c|}{$\begin{array}{c}\% \text { of recovered zinc under } \\
\text { protein in region }\end{array}$} \\
\hline & & of $B$ peak & $\begin{array}{l}\text { between Protein } \\
B \text { and low molecular } \\
\text { weight peaks }\end{array}$ \\
\hline 7 & M \& G (0.02 M-phosphate) & 1.7 & $2 \cdot 6$ \\
\hline 8 & M \& G (veronal) & $2 \cdot 4$ & $2 \cdot 4$ \\
\hline 9 & M \& $\mathrm{G}$ (veronal) & $3 \cdot 1$ & $5 \cdot 9$ \\
\hline 9 & $\begin{array}{c}\text { M \& G (veronal, pH 9) plus: } \\
0.02 \text { M-phosphate } \\
0.04 \text { M-phosphate } \\
0.06 \text { M-phosphate } \\
0.02 \text { M-borate }\end{array}$ & $\begin{array}{l}1.4 \\
0.9 \\
0.5 \\
0.9\end{array}$ & $\begin{array}{l}15 \\
52 \\
41 \\
34\end{array}$ \\
\hline 9 & $\begin{array}{l}\text { Prideaux \& Ward (1924) } \\
(0.02 \mathrm{M} \text { in phenylacetate, } 0.02 \mathrm{M} \text { in } \\
\text { borate and } 0.06 \mathrm{M} \text { in phosphate })\end{array}$ & 1.9 & 59 \\
\hline
\end{tabular}

M \& G = Miller \& Golder (1950).

\section{The effect of zinc-binding ions on gel filtration}

The peak broadening at higher $\mathrm{pH}$ values prompted an examination of the effect of phosphate added to the running buffer. (Mann (1964) showed that phosphate (2 mM) is a normal minor component of seminal plasma.) The use of universal buffer (Prideaux \& Ward, 1924) had revealed a different disposition of zinc at $\mathrm{pH} 9$ from that given by the $\mathrm{pH} 9$ veronal buffer (Miller \& Golder, 1950). Additions of phosphate (and borate, separately) to the veronal buffer, with adjustment to $\mathrm{pH} 9$, produced a marked and erratically distributed increase in the zinc contained in the region between Protein B and the low molecular weight peaks (Table 3 ). Corresponding reductions were evident in the zinc content of the low molecular weight peak. This was a quite different phenomenon from the symmetrical tailing of the peak described above.

In order to study this phenomenon further, a $0.02 \mathrm{M}$-sodium carbonatebicarbonate $\mathrm{pH} 9, I=0 \cdot 3$, running buffer was used which enabled nitrogen determinations to be carried out on the fractions without interference from veronal nitrogen. This buffer also gave an erratic distribution of seminal plasma 
zinc between the Protein B and low molecular weight peaks. Zinc citrate, with the same running buffer, revealed zinc only in the low molecular weight region.

Two entirely separate columns and seminal plasma samples from different animals gave percentages of recovered zinc between the peaks of $68 \%$ and $62 \%$, respectively, but the total recoveries of zinc from the two columns were quite different. In the first, the zinc recovery was $100 \%$ from both seminal plasma and zinc citrate; in the second, the recoveries were much lower (seminal plasma, $58 \%$; zinc citrate, $68 \%$ ). The missing zinc was found on the column by subsequent elution with $\mathrm{pH} 4$ buffer.

It is clear from determinations of nitrogen on the fractions from the seminal plasma runs that all the protein and low molecular weight nitrogenous substances were eluted from the columns by the carbonate-bicarbonate buffer and that the distribution of the nitrogenous contents of the tubes corresponded well with the u.v. protein patterns obtained.

\section{Investigation of low molecular weight components in the trailing gel-filtration u.v. peak}

Citric acid and ergothioneine were detected and measured by their respective colorimetric reactions. Measurements with a u.v. Spectrophotometer SP 800 (Pye Unicam, Cambridge, U.K.) showed a peak at $258 \mathrm{~nm}$ corresponding to ergothioneine (Heath \& Toennies, 1958) and another at $222 \mathrm{~nm}$ which could partly be ascribed to citric acid. A synthetic mixture of the appropriate concentrations of these two substances gave an absorption spectrum which was, however, not identical with that of the low molecular weight peak either at $222 \mathrm{~nm}$ or in the 265- to 300-nm region.

Amino acids are known to be present in the seminal plasma of the boar (Niwa, Mizuho, Takeda \& Ichikawa, 1952; Cegielka, 1958; Johnson, Pursel \& Gerrits, 1969) and ninhydrin-positive material was found to be present in the trailing peak. It was shown that amino acids could have a considerable effect on the absorption spectrum of synthetic mixtures of ergothioneine and citric acid both at $222 \mathrm{~nm}$ and (if traces of aromatic amino acids are present) in the 265- to 300-nm region.

Other low molecular weight substances known to be present (Mann, 1964) were tested and none appeared likely to contribute materially to the u.v. absorption spectrum of the trailing peak. The difference ( 8 to $10 \times$ ) between the absorbencies of the ergothioneine spectrogram at $256 \mathrm{~nm}$ and $280 \mathrm{~nm}$ (Heath \& Toennies, 1958) could largely account for the increased height, as mentioned earlier, of the Uvicord II trailing peak to which ergothioneine was likely to be a major contributor.

\section{DIALYSIS AND ZING SOLUBILITY EXPERIMENTS}

Three-ml samples of vesicular secretion or seminal plasma were each dialysed (Visking dialysis tubing) at $4^{\circ} \mathrm{C}$ for $42 \mathrm{hr}$, with three changes of buffer, against $200 \mathrm{ml}$ Miller \& Golder (1950) buffers $(I=0 \cdot 3)$ of $\mathrm{pH} \mathrm{6,} 7$ (phosphate), 8 and 9 (veronal). The effect of prior $1: 5$ dilution with the appropriate buffer was also observed; this dilution was carried out immediately before transfer to the dialysis sac. The results of this experiment (Text-fig. 2) showed that very little zinc 
was retained at $\mathrm{pH} 6$ and that the amount retained increased sharply with $\mathrm{pH}$. While the retention of zinc by neat seminal plasma was very similar at any one $\mathrm{pH}$ value to both the neat and diluted vesicular secretion, the diluted seminal plasma retained considerably less zinc than the neat material, especially at pH 8 and 9.

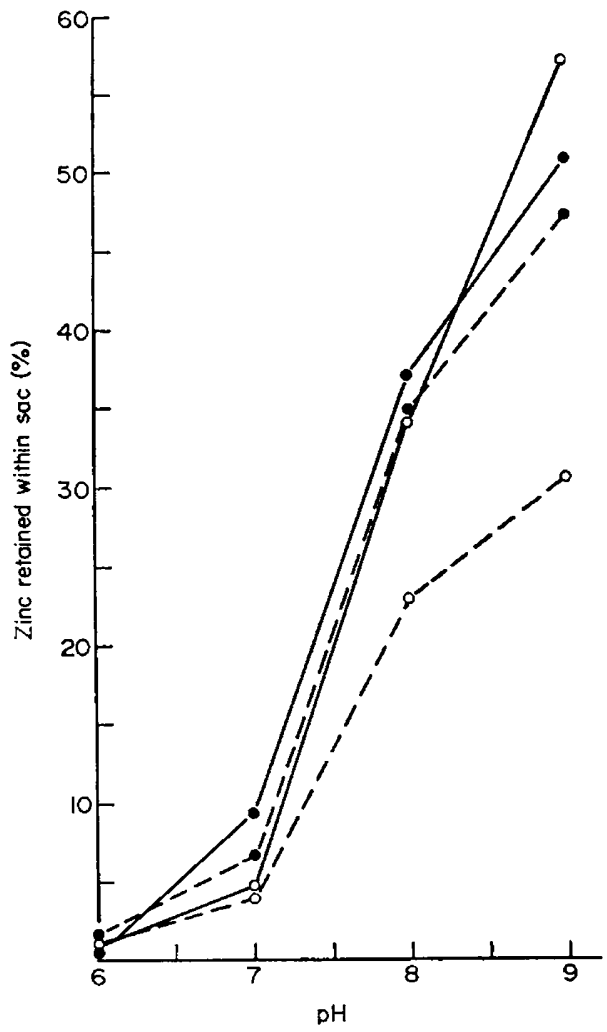

TExT-Fig. 2. Percentage of boar vesicular secretion or seminal plasma zinc retained within sac after dialysis at $4^{\circ} \mathrm{C}$ against three changes each of $200 \mathrm{ml}$ of $\mathrm{pH} 6,7,8$ or 9 Miller \& Golder (1950) buffers $(I=0 \cdot 3)$. Each sac contained $3.0 \mathrm{ml}$ fluid: vesicular secretion $(\stackrel{-}{-}$ or seminal plasma $(-.--)$, in each case either neat $(\bullet)$ or prediluted $1: 5$ with the corresponding buffer $(0)$.

In this and in many other dialysis experiments, there was a direct connection between the amount of zinc retained within the sac and the occurrence of an opalescence or a definite precipitate. It appeared that the zinc itself was being precipitated within the sac by the alterations of the conditions therein.

In studies on this phenomenon, $\mathrm{pH}$ titrations of solutions of $0.01 \mathrm{M}$-zinc acetate with $0.02 \mathrm{~N}-\mathrm{NaOH}$ were carried out in the presence of various concentrations of added citrate. It was shown that $0.0067 \mathrm{M}$-citrate, close to the mean concentration found in seminal plasma (Boursnell et al., 1972), was the lowest value which would completely obviate the appearance of a haze or precipitate of $\mathrm{Zn}(\mathrm{OH})_{2}$ even up to $\mathrm{pH} 10$. Some other substances known to be present in seminal plasma were investigated in this way as possible ligands for 
zinc, but none was found to be so effective. Glycine prevented precipitation in high concentration $(0.3 \mathrm{M})$, but then only to about $\mathrm{pH} 9$.

Apart from $\mathrm{OH}^{-}$, another possible naturally occurring ligand for zinc in seminal plasma and vesicular secretion is phosphate (about $2 \mathrm{~mm}$ in both; Mann, 1964). Tests showed that a higher concentration of citrate $(0.02 \mathrm{M})$ was required to prevent precipitation of zinc phosphate at $\mathrm{pH} 8$. This is in accord with the stability constants of these ligands given by Martell \& Sillén (1964).

\section{The solubility of zinc in veronal at $p H 8$ to 9}

Three sets of $10-\mathrm{ml}$ aliquots of a $0.082 \mathrm{~m}$ solution of zinc acetate were serially diluted by doubling dilution in water. Ten-ml vols of $0.02 \mathrm{M}$-veronal buffers at $\mathrm{pH} 8,8.5$ and 9 were added to all the tubes in each set, respectively, with adjustment to the original $\mathrm{pH}$ of the buffers in each case. After $12 \mathrm{hr}$ at $4^{\circ} \mathrm{C}$, zinc was determined in the supernatant fluids following centrifugation of the precipitates.

All three $\mathrm{pH}$ values exhibited the same phenomenon, i.e. that above the molar equivalence of zinc and veronal, very little zinc $(1 \%$ or less of the original zinc content) was found in the supernatant fluids. In the region of excess veronal at zinc concentrations $(44 \mu \mathrm{g} / \mathrm{ml})$ akin to those found in seminal plasma, between 60 and $70 \%$ of the zinc remained in solution. At the equivalence point of veronal and zinc $(650 \mu \mathrm{g} \mathrm{Zn} / \mathrm{ml})$, about $10 \%$ of the zinc was not precipitated.

When water was substituted for veronal and the $\mathrm{pH}$ of the solution of zinc acetate alone adjusted to 9 , only a very small amount of zinc $(0.8 \%$ of the initial concentration) was found in the supernatant, even at the $44 u \mathrm{~g} \mathrm{Zn} / \mathrm{ml}$ concentration.

\section{The effect of citrate on zinc dialysis}

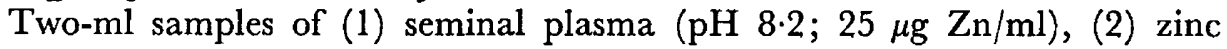
acetate $(50 \mu \mathrm{g} \mathrm{Zn} / \mathrm{ml})$ and (3) zinc citrate, i.e. (2) with added solid disodium hydrogen citrate to make $0.0067 \mathrm{M}$, were dialysed against $200-\mathrm{ml}$ quantities of (a) veronal buffer, $\mathrm{pH} 8 \cdot 2, I=0 \cdot 3$, and (b) the same buffer with added solid trisodium citrate to make $0.0067 \mathrm{~m}$, also with adjustment to the same $\mathrm{pH}$. After dialysis at $4^{\circ} \mathrm{C}$ with two changes each at 12 -hr intervals, the zinc concentrations in the sacs were measured. The results (Table 4) show the great effect of the citrate in promoting the dialysis of zinc.

\section{The behaviour of seminal plasma zinc in preparations of B Dial}

Determination of the distribution of the zinc between B Dial, A Dial and traces of insoluble residue centrifuged from the redissolved B Dial (Table 5) showed that, while $93 \%$ of the seminal plasma nitrogen was recovered, only $41 \%$ of the total zinc was retained. Of this zinc retained, $22.6 \%$ was found in the A Dial and $58.6 \%$ in the B Dial which was soluble in acetate buffer at $\mathrm{pH} 4$ $(I=0.3)$. A small insoluble residue yielded $7.75 \%$ of the zinc in the original seminal plasma $(18.9 \%$ of that recovered). Parallel nitrogen determinations enabled the $\mathrm{Zn} / \mathrm{N}$ ratios to be calculated in some cases.

Similar results were obtained in three experiments employing another seminal plasma sample. In this case, $35 \pm 3 \%$ of the zinc was recovered; of 
this, $27 \pm 2 \%$ was in the A Dial and $65 \pm 8 \%$ in the soluble B Dial. Dialysis of one of the three B Dial precipitates against water failed to remove any significant amount of zinc, but dialysis of another sample against $\mathrm{pH} 4, I=0.3$ buffer removed $99 \%$ of the zinc from the resultant centrifuged solution.

Table 4. Percentage of zinc retained in sac after dialysis of (1) boar seminal plasma, (2) zinc acetate and (3) zinc citrate against veronal or veronal-citrate buffers at $\mathrm{pH} 8 \cdot 2$

\begin{tabular}{l|c|c|c}
\hline & \multicolumn{3}{|c}{ Fluid dialysed } \\
\cline { 2 - 4 } \multicolumn{1}{c|}{ Dialysing buffer } & $\begin{array}{c}(1) \\
\text { Seminal plasma } \\
(Z n, 25 \mu g / m l)\end{array}$ & $\begin{array}{c}(2) \\
\begin{array}{l}\text { Zinc acetate } \\
\text { equivalent to } \\
50 \mu g \text { Zn/ml }\end{array}\end{array}$ & $\begin{array}{c}\text { (3) with added } \\
\text { disodium hydrogen } \\
\text { citrate to make } \\
0.0067 \text { M }\end{array}$ \\
\hline $\begin{array}{l}0.02 \text { M-veronal, pH 8.2 } \\
\begin{array}{l}0.02 \text { M-veronal } \\
\text { containing 0.0067 } \\
\text { M-trisodium citrate }\end{array}\end{array}$ & 40 & 6 & 0.6 \\
\hline
\end{tabular}

Table 5. Zinc and nitrogen contents of A Dial, B Dial and insoluble residue from B Dial prepared from $5.0 \mathrm{ml}$ boar seminal plasma

\begin{tabular}{|c|c|c|c|}
\hline & $\begin{array}{l}\text { Total } \\
Z n \\
(\mu g)\end{array}$ & $\begin{array}{c}\text { Total } \mathcal{N} \\
(m g)\end{array}$ & $\underset{(\mu g / m g)}{Z n / \mathcal{N} \text { ratio }}$ \\
\hline Original seminal plasma & 116 & $14 \cdot 5$ & $8 \cdot 0$ \\
\hline A Dial (in pH $8, I=0.015$ buffer) & $10 \cdot 75$ & $6 \cdot 53 *$ & $1 \cdot 65$ \\
\hline $\begin{array}{l}\text { B Dial (dissolved } \\
\text { in } \mathrm{pH} 4, I=0 \cdot 3 \\
\text { buffer and centrifuged) }\end{array}$ & $27 \cdot 9$ & $4 \cdot 49$ & $6 \cdot 2$ \\
\hline $\begin{array}{l}\text { Insoluble centrifuged } \\
\text { residue from B Dial } \\
\text { solution }\end{array}$ & $9 \cdot 0$ & $-\dagger$ & - \\
\hline
\end{tabular}

* Veronal nitrogen contribution deducted.

$\uparrow$ The $\mathrm{N}$ content of this material was very low.

Co-dialysis of seminal plasma and vesicular secretion against seminal plasma

These experiments were undertaken to obviate or minimize possible undesirable changes of buffer or low molecular weight components across the dialysis membrane. In initial experiments, sets of 2-ml quantities of seminal plasma of high zinc content were enclosed in dialysis sacs, and each immersed in 2-ml portions of a low-zinc seminal plasma contained in small stoppered tubes. Stirring was effected by the movement of enclosed air bubbles brought about by slow mechanical rocking of the horizontal tubes. The zinc contents were determined on the inner and outer fluids from one tube. These determinations were repeated on the other tubes in the set at intervals of time.

It was found in six such experiments, employing twelve different seminal plasma collections, that the zinc concentrations in the corresponding high and 
low pairs approached or achieved equality, but the time for this to occur, even at room temperature, was slow and variable. Equality of zinc concentration in these experiments was not achieved in $22 \mathrm{hr}$, in sharp contrast to the 4-hr period required for equilibration of zinc citrate samples at $\mathrm{pH} 8$ (containing $35 \mu \mathrm{g}$ and $15 \mu \mathrm{g} \mathrm{Zn} / \mathrm{ml}$, respectively) treated identically. In the above seminal plasma samples, no corresponding change occurred in the total nitrogen contents.

In further experiments, one high-zinc $(70 \mu \mathrm{g} / \mathrm{ml})$ seminal plasma was dialysed at room temperature against changes of a low-zinc $(13.2 \mu \mathrm{g} \mathrm{Zn} / \mathrm{ml})$ seminal plasma. Eighty-seven per cent of the difference in the zinc contents between these two seminal plasma samples was shown to be dialysable in $44 \mathrm{hr}$. Vesicular secretion (zinc content, $126 \mu \mathrm{g} / \mathrm{ml}$ ), dialysed similarly against changes of the same low-zinc seminal plasma, lost $83 \%$ of all the possible zinc in $48 \mathrm{hr}$.

\section{Comparison of the rates of dialysis of citrate and zinc from seminal plasma}

The slowness of the equilibration of the zinc concentrations across the dialysis membranes in the above experiments prompted an investigation of the comparative rates of dialysis of both zinc and citrate from samples of seminal plasma and solutions of zinc citrate.

Twenty-ml samples of fluid (seminal plasma or zinc citrate) were placed in an

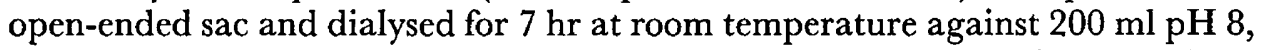
$I=0.3$ buffer with stirring. Aliquots were withdrawn at hourly intervals from inside the sac and from the buffer for zinc and citrate determinations.

These experiments showed clearly that the percentage of the seminal plasma zinc dialysing ( 15 to $20 \%$ in $3 \frac{1}{2}$ to $4 \mathrm{hr}$, according to the seminal plasma sample) was much less than that of the citrate $\left(50 \%\right.$ in $3 \frac{1}{2}$ to $4 \mathrm{hr}$ ). On the other hand, with the zinc citrate solution, while the time for $50 \%$ loss of the citrate was again $3 \frac{1}{2}$ to $4 \mathrm{hr}, 40 \%$ of the zinc had been lost from inside the sac in this time.

It is interesting that the ratio of zinc to citrate dialysing out from seminal plasma remained substantially constant throughout the 7-hr period, whereas this ratio increased two to four times, according to the seminal plasma sample, inside the sac containing the sample. No comparable rise occurred in the zinc citrate dialyses.

Preliminary experiments have shown that the rate of dialysis of the zinc from the seminal plasma is dependent on $\mathrm{pH}$.

Absence of carbonic anhydrase activity in gel filtration of seminal plasma, and in whole seminal plasma, vesicular secretion and epididymal secretion

There was no detectable carbonic anhydrase activity in samples of seminal plasma, vesicular secretion or epididymal plasma when these were examined by the method of McIntosh (1968). Samples of Protein B obtained from B Dial and of the low molecular weight peak from a seminal plasma gel-filtration fractionation were also tested but no activity was found. In these preparations, the $\mathrm{pH}$ of the buffers was never less than 4, well within the range of stability of carbonic anhydrase (Keilin \& Mann, 1940). 


\section{DISCUSSION}

This paper presents a preliminary survey by gel filtration and dialysis, employing buffers of various $\mathrm{pH}$ values and composition, of the state of zinc in boar seminal plasma and vesicular secretion. This revealed that the results obtained were very sensitive to the artificial conditions created by the buffers used. Many such explorations failed to demonstrate strong specific zinc-protein binding which could possibly account for the striking zinc-protein nitrogen correlation established by Boursnell et al. (1972).

After gel filtration at $\mathrm{pH}$ values ranging from 4 to 9 , almost all the zinc $(94 \%$ or more) was found in the fraction which contained known low molecular weight components of seminal plasma and vesicular secretion, e.g. ergothioneine and citric acid (Mann, 1964) and amino acids (Niwa, Mizuho, Takeda \& Ichikawa, 1952; Cegielka, 1958; Johnson, Pursel \& Gerrits, 1969). The occurrence of zinc and amino acids in this peak is reminiscent of the observations of Johnson, Wikström \& Nylander (1969) on gel filtration (using G-100 Sephadex) of dog prostatic secretion. These authors claimed the presence of a polypeptide ligand in the trailing peak and we are investigating the nature of the ninhydrinpositive material in the trailing peak obtained from boar seminal plasma.

At $\mathrm{pH} 7$ to 9 , a proportion of the remaining zinc was just measurable in the Protein B peak which is excluded by G-200 Sephadex. It is tentatively suggested that the excluded zinc may be present merely in an inorganic colloidal form, maintained as a sol by the presence of a protective non-specific protein layer, or possibly loosely associated with the cell débris which also appears as an excluded material.

During this work, a peculiar phenomenon was observed for which a satisfactory explanation could not be found. Although, with both vesicular secretion and seminal plasma, the zinc distribution in the low molecular weight peak was quite close to that of the normal (Gaussian) curve from $\mathrm{pH} 4$ to 9 , there was a consistent broadening of the zinc peak with increasing $\mathrm{pH}$ from 7 to 9 . This broadening was not exhibited by the citrate distribution in the low molecular weight fractions from seminal plasma, or by the zinc in samples of zinc citrate (in concentrations simulating those in seminal plasma) applied to the gel-filtration columns. It was shown that the broadening, which was thus manifest only in the presence of seminal plasma or vesicular secretion, was not due to skewness in the distribution and was partly, at least, the effect of a symmetrical tailing of the peak. The cause of this tailing may be due to the so far unknown action of a seminal plasma or vesicular secretion component.

It would appear that two different effects are occurring on these columns. In some cases, but not in others, a considerable amount of the zinc is withheld in the column and is released by washing at $\mathrm{pH} \mathrm{4}$, but this is apparently not due to trapping by seminal plasma or other nitrogenous material which is virtually absent from the fully eluted column. The other effect, that of erratic distribution of zinc in the fraction tubes, is clearly promoted by the presence of seminal plasma components and does not occur in their absence. Both these effects may be due to critical disturbances of the balance of zinc distribution between natural and artificially added ligands. 
The normal $\mathrm{pH}$ range of first ejaculates of seminal plasma is 6.85 to 7.9 , as given by Hancock (1959). Dialysis against various buffers revealed the critical importance of the composition and $\mathrm{pH}$ of these buffers on the behaviour of the zinc. At $\mathrm{pH} 6$, practically all the zinc was dialysable. With increasing $\mathrm{pH}$, even from 7 to 8 , there was a marked augmentation of the zinc $(8 \%$ to $36 \%$ ) retained within the sac in a non-dialysable form with both seminal plasma and vesicular secretion. This did not occur when citrate was included in the dialysing buffers and there was no corresponding retention of zinc when zinc citrate was dialysed in the absence of protein, whether or not citrate was included in the dialysing buffer.

These results help to explain the retention of zinc in the precipitate B Dial obtained by dialysis at $\mathrm{pH} 8$ and low ionic strength. Much of the zinc is dialysable and of that retained (35 to $41 \%$ ), most (about $60 \%$ ) is associated with the precipitated material from which it cannot be removed by dialysis against water alone. They may account for the observations of Mawson \& Fischer (1953) that about $50 \%$ of human seminal plasma zinc is retained on dialysis against water. The zinc in the boar seminal plasma B-Dial precipitate is dialysable against $\mathrm{pH} 4$ buffer.

The work on gel filtration and dialysis against buffers of various compositions demonstrated the difficulty of observing the state in which zinc occurs without destructively altering the equilibrium. The experiments in which codialysis was carried out, in order to retain as far as possible the integrity of the zinc complexes on both sides of the membrane, showed that much of the zinc was ultimately dialysable although very slowly. This slowness of zinc dialysis, in contrast to that of citrate, suggested that the zinc is partitioned between two or more ligands, some of which are of high molecular weight and probably proteins. These high molecular weight ligands may only release the zinc slowly but it must be borne in mind in considerations of comparative rates of dialysis that, on a molar basis, there are about fifteen and nineteen times as much citrate as zinc in vesicular secretion and seminal plasma, respectively (Boursnell et al., 1972).

It seems likely that the attachment of the zinc in boar seminal plasma and vesicular secretion to high molecular weight ligands is by a type of ion-binding and that the partition of the zinc between these ligands and citrate in particular is easily disturbed by the addition of buffer solutions. Further studies are presented in a following paper (Boursnell, Briggs, Lavon \& Butler, 1973) on this possible partition, which may well operate in many other biological fluids in which zinc is present in excess of that accounted for by the known zinc metalloproteins and enzymes.

\section{AGKNOWLEDGMENTS}

We would like to thank the following people for their considerable help: Mrs G. K. Foreman for the many atomic-absorption determinations; Miss D. M. Cole (Mrs Tompkin) for early trials involving micro-determination of zinc; Mrs O. M. West, Miss Z. Andani and Miss C. Reynolds for many nitrogen and citrate determinations; Dr J. E. A. McIntosh for carbonic anhydrase 
determinations; Mr D. E. Walters for statistical assessment of the normal curves; Dr R. M. C. Dawson for a gift of glycerylphosphorylcholine; Mr D. J. Kirk and $\mathrm{Mr} \mathrm{H}$. C. Toates for arranging the collections of slaughterhouse material.

Our thanks are due to Dr G. Polge and his colleagues for arranging the many semen collections.

We would like to record our appreciation of the gift of a sample of ergothioneine hydrochloride by Burroughs Wellcome Ltd.

One of us (U.L.) gratefully acknowledges the receipt of a Meat and Livestock Commission Senior Fellowship in Animal Health awarded by the Royal College of Veterinary Surgeons Trust Fund.

\section{REFERENGES}

Boursnell, J. C., Baronos, S., Briggs, P. A. \& Butler, E. J. (1972) The concentrations of zinc in boar seminal plasma and vesicular secretion in relation to those of nitrogenous substances, citrate, galactose and fructose. F. Reprod. Fert. 29, 215.

Boursnell, J. C. \& Briggs, P. A. (1969) Boar seminal plasma proteins. II. Electrophoretic identification of the haemagglutinin. F. Reprod. Fert. 19, 157.

Boursneli, J. G., Briggs, P. A., Lavon, U. \& Butler, E. J. (1973) The association of zinc with some components of boar vesicular secretion and seminal plasma. II. Ultrafiltration and ethanol-precipitation studies. F. Reprod. Fert. 34, 73.

Boursnell, J. C. \& Nelson, M. (1965) Studies on boar seminal plasma proteins. 2. An investigation on heat-coagulable component ("Fraction A"). Biochim. biophys. Acta, 104, 181.

Cegrelka, M. (1958) A qualitative study on the amino acids in the semen from ox, dog and pig. Nord. VetMed. 10, 93.

Hancock, J. L. (1959) Semen and testis characteristics and sexual behaviour of boars. F. agric. Sci., Camb. 53, 313.

Heath, H. \& Toennies, G. (1958) The preparation and properties of ergothioneine disulphide. Biochem. 7. 68, 204.

Hunter, G. (1949) The determination of ergothioneine in simple solution and in blood. Can. F. Res. 27E, 230.

Johnson, L. A., Pursel, V. G. \& Gerrits, R. J. (1969) Free amino acids of boar seminal plasma and accessory gland fluids. F. Anim. Sci. 29, 192.

Johnson, L., Wikström, S. \& NyLANder, G. (1969) The vehicle for zinc in the prostatic secretion of dogs. Scand. F. Urol. \& Nephrol. 3, 9.

Kerlin, D. \& Mann, T. (1940) Carbonic anhydrase. Purification and nature of the enzyme. Biochem. F. 34, 1163.

Kendalx, M. G. \& Stuart, A. (1963) The advanced theory of statistics, 2nd edn, Vol. 1, p. 86. Charles Griffin, London.

LAVON, U. \& BourSNELI, J. C. (1971) Characterization of boar seminal plasma, vesicular secretion and epididymal plasma proteins by gel disc electrophoresis and isoelectric focusing on polyacrylamide. 7. Reprod. Fert. 27, 227.

Lavon, U., Boursneld, J. G. \& Briggs, P. A. (1972) Further characterization of the proteins of boar seminal plasma by isoelectric focusing on polyacrylamide. F. Reprod. Fert. 30, 165.

Lavon, U., Briggs, P. A. \& Boursnell, J. C. (1973) Electrophoresis of protein fractions from boar seminal plasma, vesicular secretion and epididymal plasma. J. Reprod. Fert. 33, 39.

McIntosh, J. E. A. (1968) Assay of carbonic anhydrase by titration at constant pH. Biochem. J. 109, 203.

MANN, T. (1964) The biochemistry of semen and of the male reproductive tract. Methuen, London.

Mann, T., Davies, D. V. \& Humphrey, G. F. (1949) Fructose and citric acid assay in the secretions of the accessory glands of reproduction as indicator tests of male sex hormone activity. $\mathcal{F}$. Endocr. $6,75$.

Martell, A. E. \& Sillén, L. G. (1964) Stability constants of metal-ion complexes. Special Publications No. 17. The Chemical Society, London.

Mawson, G. A. \& Fischer, M. I. (1953) Zinc and carbonic anhydrase in human semen. Biochem. J. $55,696$.

Miller, G. L. \& Golder, R. H. (1950) Buffers of pH 2 to 12 for use in electrophoresis. Archs Biochem. 29,420 . 
Niwa, T., Mizuho, A., Takeda, S. \& Ichikawa, O. (1952) Physico-chemical studies on semen. 3. Composition of amino-acids in boar's semen by means of paper chromatography. Bull. natn. Inst. agric. Sci., Tokyo (Chiba) Ser. G. 3, 109.

Plancot, M. T. \& HaN, K. (1969) Dosage de l'activité peptidasique par une technique colorimétrique directe: application à l'étude des peptidases des mycobactéries. Bull. Soc. Chim. biol. 51, 1111.

Prideaux, E. B. R. \& WARd, A. T. (1924) Calculations on the neutralisation of mixtures of acids, and a universal buffer mixture. F. chem. Soc. 125, 426.

SPECK, J. F., Moulder, J. W. \& Evans, E. A. (1946) The biochemistry of the malaria parasite. 5. Mechanism of pyruvate oxidation in the malaria parasite. 7. biol. Chem. 164, 119. 